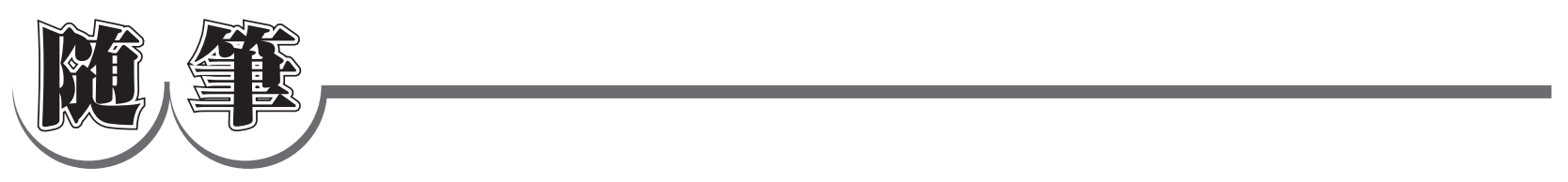

\title{
若手技術者におくる \{非許容の許容\} の考え方 ${ }^{*}$
}

\section{1.はじめに}

今年は, 多くの自然災害が発生している.わが国では, 東 北大震災, 洪水や竜巻が発生し, 多くの被害を蒙っている. 諸外国でもニュージーランドの地震, 米国の大型ハリケー ンの特異な進路, 東海岸の地震などにより想定外の災害が 発生している. 一方, 想定外の情況下で構造物や機器に対 し技術的観点から問われるのは, 安全性や信頼性 (信頼度) であろう。

製品や構造の実試験が行える場合は, 種々の条件下での 安全性や信頼性は確認できる. 実試験が実施できない場合 は, 部品試験や材料デー夕を用い,「ものづくり」における 「加工のばらつき」は「非許容」ではあるが，それらに安全 率を施し, 製作工程へと進められる. 想定外での問題発生, 特に新開発製品の許容量は未知ではあるが, 設計では安全 率，製作では公差が，それら問題に対応するために適用さ れる。このような安全率や公差では一面的であるので, 色々な要素を含めたものとして, 私は「非許容の許容」と 称している.

たとえ問題が発生しても対応できる装置の付与や検出 により, 製品の機能を想定出来れば, 安全性は担保されると 考え, 製品化される。これらは，「非許容の許容」の概念の 一つでもある．今後の「ものづくり」を担われる若い技術 者に参考になることを願い，これらのことを記述したい.

\section{2. 信頼性と信頼度}

技術分野でも「当然」と思われることが意外と忘れられ， 「值」だけが独り歩きする場合が多い。このことは, 根拠な しに「許容」や「非許容」の判定となり,信頼性低下を招く. JIS 規格では，「信頼性」とは，ある条件下で所定の期間

\footnotetext{
*原稿受付 平成23年9月4日

**正員大阪大学大学院 工学研究科 大阪産業大学大学院工学研究科 Member, Osaka University, Graduate School of Engineering and Osaka Sangyo University, Graduate School of Engineering
}

内, そのシステムが機能を十分に果たすことのできる性質 と定義されている。一方, 米国では, 想定された条件下で 所定の期間内, そのシステムが機能を果たす事の出来る確 率と定義されている. 両者の定義に大きな違いがある. 確 率算出にはデータが重要であり, その算出手順や基準も熟 知する必要から, 多くの努力が費やされたと推察される. この違いが, わが国の信頼性の発展に大きな障害となった と思わざるを得ない。ここでは, 両者の定義の違いを明確 にするため，前者を信頼性，後者を信頼度とする.

最近, 再生エネルギー問題から風力発電が盛んに使用さ れているが, 我が国の風の状況は欧州などとは異なる.我 が国では, 支柱などは耐震性が議論され, 改良されている が，ブレード設計は，欧州での規格となっていることは， 「非許容の許容」と考えてのことであろうか. 我が国では実 績を重んじるため, 実績ある国からの輸入で起こる問題で あり, 今後は, 導入するに際しては, 何を変えて, 何を変 えないかなど設計的観点から検討すべき事柄であろう. 当 然のことであるが, 設計值を決定するにはそれなりのデー 夕が必要であり, 信頼度を算出しなければならない. 紙面 の関係上, それの詳細は専門書に譲るが, 前述したように デー夕数や不明確さを勘案して, 信頼度を算出することは 可能である.

使用中にデータを採取すれば, 設計時に想定した条件の 正当性を確認すると共に, 次期設計に反映することも可能 である。「非許容の許容」には，この反映が重要であり，そ れがなければ信頼性のみを議論していることになる. 信頼 度とするには, 当初の設計時に考えた強度や荷重值の想定 など, 設計概念を理解していることが重要である. その点 を抜きにして設計に反映することは困難であろう. 当初の 設計概念を抜きにして改善すれば, 新たな問題が発生する ことは必然である. 損傷を補修するにしても, 損傷状況の 把握は重要であることは当然であるが, 初期と同じ様にす れば，同様な損傷が再発することは言及するまでもない. メンテナンス時の情況を設計にフィードバックすること は, 設計時に想定した事柄以外の事象発見に繋がり, 設計 改善となるばかりでなく, デー夕数が少なく想定した設計 
値の見直しと信頼度算出に重要な資料となる。

\section{3. 安全率と「非許容の許容」}

判断基準の明確化から, 基準の数值化や定量化の要求や 希望がある。特に，工学ではその傾向は強い。ある閾値を 設定すれば，判断の統一性が保たれ，万人が納得し易くな る。その一方で，その值の算出過程や手順が明らかでない 場合は，判断根拠が不明確となり，信頼度が得られないこ とは明白である。しかし，数值化は不変と捉えられ，誤判 断が防げることからある種の信頼度と見做され，数值化の 適用が好まれる．技術者や工学者は，これは真の信頼度で はないことを十分に認識することが重要である。安全率， 安全係数は，この考えを基に適用される．材料には，その 特性にばらつきがあり，その存在を許容して強度を決定す るために安全率が適用される，更に，構造体施工には，そ れなりのばらつきも発生し, 構造体を使用する環境や情況 により，所定の期間内に損傷が発生する可能性もあるの で，安全率が適用される，すなわち，ばらつきや施工差な どは在ってはならない「非許容」であるが，それを無くす ことの技術的困難さから，ばらつきを「許容」とせざるを 得ない。それらは，「非許容の許容」である。もちろん，可 能な限り不確定性を少なくするために, 材料特性值をサン プリング試験により求め，信頼水準（求めた值となる信頼 度）を基に，設計值を決定する手法が用いられる．(航空機 などでは A 值, B 值として求められている.) 換言すれば, 「非許容の許容」の概念が無ければ, 全ての事が明確でない 限り制作できないことになり，ものづくりは不可能であろ う.また，使用者側からも信頼は得られないことにもなる。

\section{4. 事 故 例}

過去の代表的な事故を整理された「失敗学」(畑村洋一郎 著）は，多くの知識・教訓を得ることが出来る適切な書物 である。事故から得る知識は，新たに設計する際，未知の 部分の洗い出しに有用であるが，本節では，新たに設計さ れた場合の問題点に焦点を当て「非許容の許容」について の考え方を整理する。

\section{1 タコマ橋の崩壊事例}

アメリカ西海岸のワシントン州タコマ市の橋は, ワシン トン州北西部の入り組んだ湾の海峡部の渓谷を跨ぐ形で 設置, 1940年 3 月に完成した. 橋の中央スパンは $853 \mathrm{~m}$, 橋 床の幅は $11.9 \mathrm{~m}$ ，長さに比べて幅の狭い橋であり，新らた な設計を基に造られた吊り橋であるが, 完成後わずか 4 ケ 月後, 毎秒 $19 \mathrm{~m}$ の横風のために崩壊した.

崩壊については，当時，不明点が多く，解明のために事 故調查委員会が結成された。現象の把握に風洞実験がワシ ントン大学で実施され，橋の挙動が撮影された。それによ ると，最初は，橋の長手方向に波打つ振動モードであった が, その振動による補強部材の疲労破損により, その後, 長 手方向にねじれる振動モードに変化し，最終的に崩落する 状況となることが明らかとなった。この状況は，当時，橋 の崩壊情況を撮影していた結果と一致しており，振動現象
であることが判明した。

事故調査委員会により「タコマ橋は，構造物の設計にお いて考慮されるべき静的な荷重（風を含む）に対して，設 計的にも施工的にも十分な配慮が払われていた。したがっ て本事故は, 考慮されていない動的な力, すなわち風によ る過度の振動に原因があると考えられる. 今後, つり橋に 及ぼされる空気力学的な影響について, 実験的にも理論的 にも，研究を進めることが望ましい」とする報告書が提出 された。この事故の教訓から, 現在の橋梁が, 設計可能と なったと言っても過言ではない.

この事故は，未知の現象で発生したものであると考え る. 当時，橋梁の第 1 級の設計者によって設計されたつり 橋であるが, 未知現象に対する信頼度の算出は不可能であ る良き事例である.新たな (チャレンジ) 設計・製作は,「非 許容の許容」によらなければ出来ないことである. 事故を 起こさないことが何よりも重要であるが, 期せずして発生 した場合には, その後の対応が重要であることは, この事 故は教えている.

\section{2 ジェット旅客機コメットの墜落事例}

未到の速度と高度を飛ぶ初のジェット旅客機は, 運航シ ステムの新規開発とイギリス空軍と $\mathrm{BOAC}$ (ブリティッシ ユ・エアーウェイズ）の協力で， 2 年間の入念な準備期間 の後，製作され，世界の主要各地に運航した。1952年 5 月 は，ヒースローとヨハネスブルグ間の商用運航が行われ， 所要時間の半減と共に天候の影響を受けにくい高い高度 を飛行することによって快適性も生じたことから, プロペ ラ機以上に人気を博し，多くの航空会社に注目された。と ころが, 就航から 1 年の間に 3 機が離着陸時の事故で失わ れた。しかし，高速機特有の挙動に不慣れなパイロットの 誤操縦によるものと判断され, 特別な設計変更はされなか った。

その後，1954年 1 月イタリア近海を飛行中に墜落，乗客 乗員の35名全員が死亡した. 回収された残骸の状況から空 中分解が懸念され，コメット全機の運航が停止されたが， 問題部分と思われた個所が改修され，運航が再開された。 ところが, 運航再開後の 4 月にもイタリア近海を飛行中の 南アフリカ航空の機が墜落し, 乗客乗員21名全員が死亡し た. 2 度の事故から, コメットの強度, 構造及び性能が, 定 められた安全性及び環境保全の技術上の基準に適合して いないとされ，全機運航停止となった。これがコメット機 墜落の概要である.

イギリスは，徹底的な調査を実施する上で，飛行状況で の航空機胴体の挙動を模擬するために, 巨大な水槽を建造 し, 航空機を水槽に沈め, 胴体内に水圧を作用させ，繰り 返し飛行による再現実験が行われた。 その結果，当時，夜 間飛行でも方向確認するために星の位置の観測用空が操 縦室の天井にあり, その空枠の角から亀裂が発生, 成長し て機体が破裂することが報告された。

この設計では, 地上と飛行高度での圧力差による機内の 疲労現象や確認方法の欠落から生じた現象であり, 未知の 技術問題に属するものであろう。 その後, 航空機設計にフ エイルセーフ設計やたとえ龟裂が発生しても致命的な崩 壊とならない耐損傷設計へと発展している. 未知の部分を 明確化し, より精度の高い設計へと発展させている. 近年 
は，これに加えて，マルチサイトクラッキングなどの現象 も確認されているが，記述は省略する。

航空機であるが故に機体重量から「非許容の許容」の取 り方に限度があったと思われるが, 重要な点は, 事故が設 計当初には想定されない現象で発生したことにある.問題 は，事故について多くの議論がなされたが，誤った結論が 導かれたことにある．結論が誤れば「非許容の許容」も何 の意味もない事例と言える.

\section{5. 最後に}

構造体や機構の設計・製作や運用に際し, 作用する負荷 条件, 材料特性や加工精度など全てを考慮することは容易 ではない．ある程度の未知（多くは不確定とされる）部分 を許容しなければ，合理的な設計・製作や運用は出来な
い.この「未知」の部分が「非許容の許容」であり,「無知」の 部分にこの考えを適用することは絶対に避けなければな らない. 未知と無知が混同され, 単なる安全率として取り 扱われていることは見逃せないことである. 製品の改善や 修正が行われた場合, このことが大きな問題となりうるの は, リコールや保証問題に発展していることからも, 周知 のことである。このように, 事故例から多くを学ぶことが 出来る. 当然, 効率や経済性なども考慮すべきであるが, 「非許容の許容」とのバランスが, 重要であることは, 言及 するまでもない.

若い技術者を対象に筆者の思いを書かせていただいた が, 浅学のために意眓したことが伝わったかどうかは疑問 である.多くのことから学ぶことの重要性を汲み取って頂 き,より良き「ものづくり」に対応いただければ幸いである. 